\title{
SOME COMMENTS ON RARE AND ENDANGERED LIVERWORTS IN MAINLAND CHINA
}

\author{
ЗАМЕТКИ О РЕДКИХ И НАХОДЯЩИХСЯ ПОД УГРОЗОЙ \\ ИСЧЕЗНОВЕНИЯ ПЕЧЕНОЧНИКАХ МАТЕРИКОВОЙ ЧАСТИ \\ КИТАЯ
}

\author{
RUI-LIANG ZHU ${ }^{1}$, REN-LIANG HU ${ }^{1} \&$ YI-JIE MA ${ }^{2}$
}

\begin{abstract}
Based on our field and literature surveys, four types of endangered liverworts are recognized for the mainland Chinese bryoflora: A type - rare and endemic species; B type widespread species becoming rare; $C$ type - species important to scientific research; and D type - species with a widely disjunctive distribution. We put forward six major causes for the decline of liverwort populations in mainland China. These are: 1) over-cutting of natural forests; 2) ill-planned public construction works; 3) cultivation of edible mushrooms and medicinal plants; 4) inappropriate conservation practices; 5) over collection of leaves with epiphyllous liverworts; and 6) air pollution. A preliminary list of 18 species of rare and endangered liverworts are provided for mainland China. The following measures are proposed to help conserve these liverworts: 1) more investigations of local bryoflora; 2) establishment of more nature reserves; and 3) public education and dissemination of information about nature conservation and endangered plant species.
\end{abstract}

Резюме

На основании наблюдений в природе и анализа литературных данных о редких и находящихся под утрозой исчезновения печеночников материковой части Китая выделено четыре типа таких видов: А - редкие и эндемичные виды; В - широкораспространенные виды, сокращающие свою численность; С - виды, представляющие интерес для научных исследованнй; D - виды с широко дизъюнктивными ареалами. Обсуждаются шесть основных причин, определяющих сокращение популяций печеночников: 1) интенсивные рубки естественных лесов; 2) отсутствие комплексного планирования строительных работ; 3) вырацивание съедобных грибов и лекарственных растений; 4) неудовлетворительные работы по охране растений; 5) слишком интенсивный сбор листьев, на которых растут эпнфильные печеночники; 6) атмосферное загрязнение. Дан предварительный список 18 редких и исчезающих печеночников материкового Китая. Для более успешного решения проблем охраны необходимы: 1) более интенсивные исследования локальных брнофлор; 2) организашия охраняемых территорнй; 3) просвещение.

\section{INTRODUCTION}

Mainland China, covering a vast area of about 956,000,000 sq. $\mathrm{km}$. and with a broad altitudinal range between -155 to $8848 \mathrm{~m}$ above sea level, is located on the eastern edge of Asiatic continent. The climate varies from tropical, subtropical in the south to temperate and boreal in the north. Its topography and geology are equally complex and variable. Owing to these diverse physical conditions, liverworts are very rich in mainland China where about
750 taxa (including subspecies and varieties) have been reported (Li 1990; Piippo 1990; Zhu \& al. 1992; Zhu \& Wang 1992). For a variety of reasons, some liverworts have become, or are becoming, rare and endangered locally. However, until now, studies on endangered liverworts have not attracted the serious attention of mainland Chinese bryologists, and only one such study was reported (Cao 1992). Moreover, the importance of liverworts in the biological diversity of China has not been well under-

\footnotetext{
1. Department of Biology, East China Normal University, Shanghai 200062, China.

2 - Baishanzu Nature Reserve, Qinyuan 323808, Zhejiang Province, China.
} 
stood. We think that it is urgent and timely to investigate and protect the endangered Chinese liverwort flora.

\section{Types of Rare And Endangered Mainland CHINESE LIVERWORTS}

Considering all factors, we classify the rare and endangered Chinese liverworts into four types. Our grouping basis does not depend entirely on the existing size of populations or the total range of a species as is the case of IUCN system of classification of endangered species. We think that it is premature at this time to adopt the IUCN system because of the rather incomplete knowledge of distribution of hepatics in mainland China.

Type A. Rare and Endemic taXa. Examples are Jungermannia breviperianthia $\mathrm{Gao}$ and Trichocoleopsis tsinlingensis Chen ex M.-X. Zhang. Currently, there are about 80 species of liverworts described as new to science based on specimens collected from mainland China. Many of them remain endemic to China today. However, their total ranges are imperfectly known, and some species seem to have a doubtful taxonomic value. There is a need to conduct monographic revision before a species be classified as type $A$ representative.

Type B. WIDESPREAD SPECIES BECOMING RARE ON THE MAINLAND. Examples are Schiffneria hyalina Steph. and Haplomitrium mnioides (Lindenb.) Schust.

Type $C$. BIOLOGICALLY UNIQUE SPECIES IMPORTANT TO SCIENTIFIC RESEARCH, i.e., Isotachis japonica Steph. and Zoopsis liukiuensis Horik.

Type $D$. SPECIES WITH A WIDELY DISJUNCTIVE DISTRIBUTION In China, such as Cololejeunea magnilobula (Horik.) Hatt. and Scaphophyllum speciosum (Horik.) Inoue.

\section{Causes of Decline of Liverworts in MaInland China}

Having collected bryophytes in many parts of China in past several years, we observe that the decline of the numbers of liverwort species in many places is mainly due to the following causes:

\section{OVER CUTTING OF NATURAL FORESTS}

As a result of rapid population growth, large areas of natural forests in mainland China have been cleared for settlement expansion and es- tablishment. This has led to the disappearance of forest habitats rich in liverwort flora. For example, Haplomitrium mnioides is rarely collected these days except in a few well-preserved nature reserves.

\section{ILL-PLANNED PUBLIC CONSTRUCTION WORKS}

In recent years, tourism has developed rapidly in mainland China along with economic progress. More and more people visited nature reserves and forest parks. To meet the needs of this sudden influx of visitors, new hotels, residential buildings, water reservoirs and roads were built. In doing so, type localities of plant species, areas rich in liverworts, and other environmental consequences had not been given full consideration before the physical construction started. This has led to the disappearance of well known species of liverworts from many local sites. Zhu \& al. (1992) collected a new species, Cololejeunea latistyla, from Baishanzu Nature Reserve in Zhejiang Province, just before a new road was constructed in 1991 cutting through the type locality. Since, this rare Chinese endemic seems to have disappeared from the general vicinity in spite of our repeated attempt to locate it.

\section{Cultivation of edible mushrooms and MEDICINAL PLANTS}

The agaric (Xianggu) mushrooms is one of the main sources of income for peasants living in mountainous parts of East China. To grow the mushroom, peasants often placed inoculated logs inside the evergreen broad-leaved forest which is also the habitat for several uncommon liverwort species in East China. Owing to poor forest management and often destructive mushroom harvesting practices, the forest environment became degraded over a period of time. A good illustrative case is Trichocoleopsis tsinlingensis Chen ex M.-X. Zhang which grows on the soil and rotten logs inside forest on $\mathrm{Mt}$. Fengyang in Zhejiang Province where many local peasants cultivated Xianggu mushrooms underneath the same forest canopy. Consequently, large populations of $T$. tsinlingensis were seen trampled upon by human activities and became exterminated. Similarly, cultivation of medicinal plants, such as Panax schin-seng Nees, in some mountainous areas also led to the clearing away of local liverwort populations as un- 
wanted weeds.

\section{INAPPROPRIATE CONSERVATION PRACTICES}

Presently, much national attention is focused on the conservation of endangered seed plants in China. To prevent unwanted human disturbance, special installations, such as cement walls or metallic rails, are built around individuals of the endangered plant species growing inside the protected area. This is true in the case of Abies beshanzuensis M.-H. Wu which is, today, one of the twelve most endangered plants in China and the world over (SSC 1987). Unfortunately, these installations caused a radical change of habitat conditions. At Baishanzu Nature Reserve which is the type locality of $A$. beshanzuensis, we collected 20 epiphyllous liverworts before the installation of protection railing. Today, only five species are found in situ.

\section{Over collection of leaves with EPIPHYLLOUS LIVERWORTS}

Epiphyllous liverworts are rather rich in southern China. However, some species have become rare because of the over collection of leaves on which they grow. For example, in some coastal provinces, the leaves of Indocalamus tessellatus are used for wrapping the rice "zongzi", a traditional Chinese food preparation. Every year a large quantity of Indocalamus leaves are harvested for this purpose. Unfortunately, about $2 / 3$ of the epiphyllous liverwort taxa in East China grow on Indocalamus leaves. Thus, the survival of these liverworts has become threatened by the continuing consumption of Indocalamus leaves.

\section{Air Pollution}

As a result of rapid industrial development, air pollution is becoming more and more serious in many parts of China. Bryophytes in southwestern China were found to be detrimentally affected by acid rain (Gao \& Cao 1992). In Shanghai area, liverworts were rich in the past. In fact, Stephani described in 1921 an interesting species, Plagiochila shanghaica, which has not been seen again in the type locality.

\section{A Preliminary List of Rare and Endangered Mainland Chinese Liverworts}

The preparation of the red list is based on our field observation and literature survey. Since there are several species of liverworts, includ- ing some of the endangered candidates, that have not been well collected across mainland China, the listing can only be considered preliminary. Furthermore, the list excludes all taxonomically doubtful Chinese records, such as Herberta huerlimannia, Frullania philippinensis, Lejeunea laetevitem, Scapania aspera, etc. Relevant comment on the local range is provided for each of the entries, together with their classified status of rare and endangerment.

Cololejeunea magnilobula (Horik.) Hatt.

This is a rare Chinese endemic (Chen \& Wu 1964). Horikawa (1934) first described it from Mt. Taihei, Taiwan Province. In 1990, R.-L. Zhu and company found it in Baishanzu Nature Reserve, Zhejiang Province (Zhu \& al. 1992). The latter becomes the only known locality on the mainland. Owing to local construction works, this rare species has disappeared locally. Between 1991-1993, we went to Baishanzu Reserve three times to locate it unsuccessfully. Thus, this interesting species is known from Taiwan with a reported locality in Zhejiang Province.

Endangered status: Type D.

\section{Cololejeunea ornata Evans}

This species has a disjunct distribution in E. Asia and N. America (Mizutani 1986). In mainland China, it is rather rare. Liu \& al. (1988) first recorded it from Anhui Province. Recently, we collected it from Mt. Fengyang in Zhejiang Province. According to our field observation, this liverwort grows on leaves inside lowland forests. With fast conversion of forest into agricultural land, especially in the localities mentioned above, the continued survival of $C$. ornata is seriously threatened.

Endangered status: Type D.

\section{Gongylanthus ericetorum (Raddi) Nees}

This species is very rare in mainland China. Until now, it is known only from Mt. West Tianmu, Zhejiang Province ( $\mathrm{Hu} \&$ Wang 1981) where we have had much difficulties locating the populations.

Endangered status: Type D.

\section{Gottschea philippinensis Mont.}

This is a rather common species in mossy forests in southeast Asia (Inoue 1985). However, it is rather rare in mainland China (Zhu \& Wang 1994). According to our survey, this species is found only in forests at high altitude. It seems to have disappeared from forests at low altitude.

Endangered status: Type D.

Haplomitrium blumii (Nees) Schust.

This species is uncommon in mainland China. It grows on soil inside forest with a high humidity. For 
reason of its poor adaptation to dry condition, populations disappear much more faster than other species of liverworts under-similar human disturbances.

Endangered status: Type $\mathrm{C}$.

Haplomitrium mnioides (Lindenb.) Schust.

This delicate hepatic was rather common in southern China in the past ( $\mathrm{Hu}$ 1987). In recent years, it has been over collected for scientific research purpose.

Endangered status: Type B.

Isotachis japonica Steph.

The genus Isotachis was first proposed by Mitten in 1855. Since then, the systematic position of this genus and its family, Isotachaceae, in the Hepaticae has been disputed (Inoue 1974). I. japonica is the only species of this genus in eastern Asia and possesses important research value. The species is known only from Guangdong and Yunnan Provinces in mainland China (Zhu \& Wang 1994).

Endangered status: Type C.

Jungermannia breviperianthia Gao in Gao \& Zhang

Gao \& Zhang (1981) first described this species. In a decade, it has lost a large portion of its range to human disturbances (Cao 1992). The species is known at present from Jilin and Liaoning provinces (Koponen \& al. 1983; Gao \& Zhang 1981).

Endangered status: Type A.

Jungermannia flagellalioides (Gao) Piippo

Known only from the type collection, this species is fast losing its habitats even in its type locality, Mt. Funhuan, Liaoning Province (Cao 1992). There is a danger that it will soon become extinct if no conservation measure is introduced.

Endangered status: Type A.

\section{Kurzia sinensis Chang in Chang \& Gao}

This species was first described by Chang \& Gao in 1984. Its only known locality, Mt. Nanyandan, is being destroyed by the rapid development of tourism.

Endangered status: Type A.

Marsupella fengchengensis Gao

Known only from Liaoning Province, this species is losing its habitat fast at the type locality, Mt. Funhuan, Liaoning Province (Cao 1992).

Endangered status: Type A.

\section{Metzgeria liaoningensis Gao}

This species has lost most of its habitats on Mt. Funhuan, Liaoning Province, the type locality (Cao 1992). The other known population in the nearby Heilongiiang Province is equally threatened by human activities.

Endangered status: Type A.
Neotrichocolea bissetii (Mitt.) Hatt.

This is an East Asiatic endemic. In mainland China, it was first reported from Mt. Huang in Anhui Province (Chen \& Wu 1965). Owing to human disturbances and over collection for instructional purpose, natural populations in East China have declined significantly these days.

Endangered status: Type C.

\section{Plagiochila shanghaica Steph.}

This species possesses a rather narrow range in mainland China, known only from Mt. She in Shanghai area and Wu County in Jiangsu Province ( $\mathrm{Li} \&$ Gao 1986; Xu 1989). With massive urbanization going on at present around these localities, the survival of this species is in doubt. Outside China, the species is known from Japan (Inoue 1982).

Endangered status: Type D.

Scaphophyllum speciosum (Horik.) Inoue

This well known monotypic genus is endemic to China. Described first by Inoue in 1966, it has a very restricted range in mainland China, known only from Dulongjiang, Yunnan Province (Inoue 1966; Zhu \& Wang 1994), and is confined to high altitude above $2000 \mathrm{~m}$. In Taiwan, the same species is found on forest floor between 2000 to $2400 \mathrm{~m}$ (Vana \& Inoue 1983) where local populations rarely produce perianth and vegetative branches. Because of its own reproductive limitation and the increasing economic activities at high altitude areas, this species has become endangered in recent years.

Endangered status: Type D.

\section{Schiffneria hyalina Steph.}

The genus Schiffneria possesses important study value in bryophyte systematics because of its transitional position between the thalloid and leafy liverworts. In the past, this species was rather common in South China. From 1987 to 1992, we made several bryological expeditions to many places in South China, but found it only in Mt. Babao Nature Reserve in Guangdong Province. Over collecting for teaching purpose is one of the many causes of its diminishing range in mainland China.

Endangered status: Types B.

\section{Trichocoleopsis tsinlingensis Chen ex M.-} X. Zhang

The genus Trichocoleopsis, which includes only two species in the world, is endemic to E. Asia. T.tsinlingensis, an endemic in mainland China (Shaanxi, Fujian and Yunnan), was first described by M.-X. Zhang in 1982 (Gao \& Cao 1988). Recently, we discovered a new population in Zhejiang Province. Our survey reveals that this species has become rare at low altitude in many places.

Endangered status: Type A. 
Zoopsis liukiuensis Horik.

The genus Zoopsis represents the transitional morphology between a thallus and a cormus. In this genus, $Z$. liukiuensis is the only species distributed in the Northern Hemisphere. In mainland China, this interesting taxon was first reported by $\mathrm{Wu} \&$ Lin (1978). In 1988, we collected it from Daweishan Nature Reserve in Yunnan Province (Zhu \& Wang 1994). According to Mizutani \& Chang (1986), this species is known also from Zhejiang Province. However, we have not been able to locate the species in Zhejiang.

Endangered status: Type C.

\section{Discussion}

To preserve the bryological diversity of Chinese flora, there is an urgent need to protect the rare and endangered liverworts in mainland China. We recommend the following measures to help conserve them in accordance to the existing socio-economic conditions in mainland China.

(1) More investigations of local bryoflora. At present, only five provinces in mainland China have a relatively well investigated hepatic flora. Several large genera such as Cololejeunea, Frullania, Jungermannia, and Plagiochila need modern revisionary study.

(2) Establishment of more nature reserves. There are about 530 nature reserves and 254 forest parks in mainland China. However, compared to other developed countries, the ratio of the areas of all nature reserves to the total areas of the country is still low. In addition, type localities of many rare Chinese species, such as Cephaloziella flexuosa Gao \& Chang and Kurzia sinensis, are not included in any nature reserve.

(3) Public education and dissemination of information about nature conservation and endangered liverworts. In mainland China, nature conservation is a new undertaking. It is still in its initial stage of development. At the moment, many people have only a poor understanding of the importance and the necessity to protect nature and the endangered plants and animals as well. As such, a listing of the country's rare and endangered liverworts, which is a sure way to get the attention of common people and government authority, should be published as soon as possible. When completed, this published list should be widely circulated among staff members of nature reserves and forest parks, in addition to the governmental offices concerned. Lastly, to avoid any ecological disasters resulted from poorly planned construction works, the government should be made to require an environmental impact assessment study before permitting any public construction works to start.

\section{ACKNOWLEDGEMENTS}

We are deeply indebted to Dr. B. C. Tan of Harvard University Herbaria for reading, edit- ing and preparing the manuscript for publication. We like to thank Mr. Jian-Xiang Yao, Director of Qingyuan Bureau of Forestry, Zhejiang Province, for his assistance in coordinating the field works. We are also grateful to $\mathrm{Mr}$. Xiao-Rong Mao and Mr. Huan-Zhong Cai of Baishanzu Nature Reserve in Zhejiang Province for their assistance provided during our field survey.

\section{Literature Cited}

CAO, T. 1992. Endangered bryophytes in Northeast China. - Biol. Conseroation 59: 243-245.

CHANG, K.-C. \& C. GAO 1984. Plantae novae Hepaticarum Sinarum. - Bull. Bot. Res. 4: 83-99.

CHEN, P.-C. \& P.-C. WU 1964. Study of epiphyllous liverworts of China. I. - Acta Phytotax. Sinica 9 (3): 213-276.

CHEN, P.-C. \& P.-C. WU 1965. The preliminary study of the bryophytes of Mt. Hwangshan. - Observationes ad Florilam Hwangshanicam: 1-59.

GAO, C. \& T. CAO 1992. A preliminary study on indication of bryophytes to air pollution (including acid rain) in southwest China. - Chinese J. Appl. Ecol. 3 (1): 81-90.

GAO, C. \& G.-C. ZHANG 1981. Flora Hepaticarum Chinae Boreali-Orientalis. - Science Press, Beijing.
GAO, C.-H. \& T. CAO 1988. A study of Trichocolea Dum., Trichocoleopsis Okam. and Neotrichocolea Hatt. (Hepaticae) in China. - Investigatio et Studium Naturae 8: 24-37.

HORIKAWA, Y. 1934. Monographia Hepaticorum AustraliJaponicarum. - J. Sci. Hiroshima Unio. Ser. B, Div. 2,2: 101-325.

HU, R.-L. 1987. Bryology. - High Education Press, Beijing.

HU, R.-L. \& Y.F. WANG 1981. A survey on the bryophyes from the Tian-Mu Mountain in Zhejiang Province. - $J$. East China Normal Univ. (Nat. Sci, ed.) 1: 85-104.

INOUE, H. 1966. Scaphophyllum, a new genus of the Jungermanniaceae. - J. Jap. Bot. 41: 266-269.

INOUE, H. 1974. Illustrations of Japanese Hepaticae. - Tsukiji Shokan Publishing Co., Tokyo. 
INOUE, H. 1982. Studies on Plagiochila shanghaica Steph. from Japan. - J. Jap. Bot. 57: 304-308.

INOUE, H. 1985. Studies on Taiwan Hepaticae VI. Schistochilaceae. - Bull. Natn. Sci. Mus. Ser. B (Bot.) 11: 109. 118.

KOPONEN, T., C. GAO, J.-S. LUO \& J. JARVINEN 1983. Bryophytes from Mt. Chang-Bai, Jilin Province, Northeast China. - Ann. Bot. Fennici 20: 215-232.

LI, D.-K. 1990. Two new records of hepatics from China. Inoestigatio et Studium Naturae 10: 139-140.

LI, D.-K. \& C.-H. GAO 1986. The preliminary survey of the bryoflora in Shanghai region. - Investigatio et Studium Naturae 6: 135-148.

LIU, Z.-L., X.-H. GUO \& R.-L. HU 1988. Investigation on the epiphyllous liverworts from southern part of Anhui Province. - J. East China Normal Unio. (Nat. Sci. ed.) 4: 89-96.

MITTEN, W. 1855. Hepaticae. - In: Hooker, J. D., Botany of Antarctic Voyage, ool. II. London.

MIZUTANI, M. 1986. Notes on the Lejeuneaceae 11. Cololejeunea spinosa and its related species in Japan. - J. Hattori Bot. Lab. 60: 439-450.

MIZUTANI, M. \& C. CHANG. 1986. A preliminary study of Chinese Lepidoziaceae flora. - J. Hattori Bot. Lab. 60: 419-437.

PIIPPO, S. 1990. Annotated catalogue of Chinese Hepaticae and Anthocerotae. - J. Hattori Bot. Lab. 68: 1-192.
STEPHANI, F. 1917-1924. Species Hepaticarum. VI, Suppl. ad. vols. I-V. Geneve.

SSC. 1987. The most endangered twelve animals and twelve plants. - Nerosletter of the SSC 8: 21-24.

VANA, J. \& H. INOUE 1983. Studies on Taiwan Hepaticae. V. Jungermanniaceae. - Bull. Nat. Sci. Mus. ser. B (Bot.) 9: 125-142.

WU, P.-C. \& P.-J. LIN 1978. A preliminary observation on the Hepaticae of the island Hainan, China, and their phytogeographical relationship. - Acta Phytotax. Sinica 16(2): 56-71.

XU, B.-S. (ed.) 1989. Cryptogamic Flora of the Yangtze Delta and Adjacent Regions. - Shanghai Scientific and Technical Publishers, Shanghai.

ZHANG, M.-X. 1982. Eine neue Trichocoleopsis im Qinling (China). - Acta Bot. Yunnanica 4(3): 171-172.

ZHU, R.-L. \& Y.-F. WANG 1992. A preliminary revision of epiphyllous liverworts from Dinghu-shan. - J. East China Normal Unio. (Nat. Sci. ed.) 2: 90-97.

ZHU, R.-L. \& Y.-F. WANG 1994. Four noteworthy Chinese liverworts. - J. East China Normal Univ. (Nat. Sci. ed.) 4: 125-130.

ZHU, R.-L., G.-Z. ZHANG \& X.-R. MAO 1992. Resources of epiphyllous liverworts in Baishanzu Nature Reserve of Zhejiang Province. - J. Plant Resources and Entoironment 1(3): 19-23. 